\title{
Molecular Characterization of Citrus tatter leaf virus Historically Associated with Meyer Lemon Trees: Complete Genome Sequence and Development of Biologically Active In Vitro Transcripts
}

\author{
Satyanarayana Tatineni, Mohammad R. Afunian, Mark E. Hilf, Siddarame Gowda, \\ William O. Dawson, and Stephen M. Garnsey
}

First, second, fourth, fifth, and sixth authors: Citrus Research and Education Center, University of Florida-IFAS, Lake Alfred 33850; third author: United States Department of Agriculture-Agricultural Research Service (USDA-ARS), 2001 S. Rock Road, Fort Pierce, FL 34945; and first author: USDA-ARS and Department of Plant Pathology, University of Nebraska, Lincoln 68583.

Current address of second author: Department of Plant Pathology and Microbiology, University of California, Riverside 92521.

Accepted for publication 17 December 2008.

\begin{abstract}
Tatineni, S., Afunian, M. R., Hilf, M. E., Gowda, S., Dawson, W. O., and Garnsey, S. M. 2009. Molecular characterization of Citrus tatter leaf virus historically associated with Meyer lemon trees: Complete genome sequence and development of biologically active in vitro transcripts. Phytopathology 99:423-431.

Citrus tatter leaf virus isolated from Meyer lemon trees (CTLV-ML) from California and Florida induces bud union incompatibility of citrus trees grafted on the widely used trifoliate and trifoliate hybrid rootstocks. The complete genome sequence of CTLV-ML was determined to be 6,495 nucleotides (nts), with two overlapping open reading frames (ORFs) and a poly (A) tail at the $3^{\prime}$ end. The genome organization is similar to other capilloviruses, with ORF1 (nts 37 to 6,354) encoding a putative 242-kDa polyprotein which contains replication-associated domains plus a coat protein (CP), and ORF2 (nts 4,788 to 5,750), which is located within

ORF1 in a different reading frame and encodes a putative movement protein. Although the proteins encoded by CTLV-ML possesses 84 to 96\% amino acid sequence identity with strains of Apple stem grooving virus (ASGV), we observed two strikingly different regions in ORF1: variable region I (amino acids 532 to 570) and variable region II (amino acids 1,583 to 1,868 ), with only 15 to 18 and 56 to $62 \%$ identities, respectively, with the corresponding regions of ASGV strains. Conditions for a herbaceous systemic assay host were optimized in which the wildtype virus induced systemic infection in Phaseolus vulgaris cv. Light Red Kidney (LRK) bean plants at 19 or $22^{\circ} \mathrm{C}$ but not at higher temperatures. In vitro transcripts generated from full-length cDNA clones induced systemic symptoms on LRK bean plants similar to that of the wild-type virus. Replication of the recombinant virus was confirmed by hybridization of a $5^{\prime}$ positive-stranded RNA-specific probe to a genome-sized RNA and by reverse-transcription polymerase chain reaction.
\end{abstract}

Citrus tatter leaf virus (CTLV) was initially reported from California as a latent infection in Meyer lemon trees (Citrus limon (L.) Burm. F. hyb.), which was likely originated when infected Meyer lemon was introduced into the United States from China in 1906 (6,16). Bioindexing revealed CTLV in all indexed Meyer lemon trees but not in other selections of foreign and domestic citrus cultivars (26,27). Subsequently, CTLV was also reported in commercial Meyer lemon trees in Florida (5). CTLV induces a bud union incompatibility of citrus trees grafted on trifoliate orange or on its hybrid rootstocks $(3,16,17)$. In Florida, due to the susceptibility of sour orange rootstock to a bud union incompatibility induced by decline isolates of Citrus tristeza virus (CTV), the horticulturally desirable sour orange rootstock has been replaced with CTV-tolerant trifoliate hybrid rootstocks, which are susceptible to a bud union incompatibility associated with CTLV infection. The trifoliate hybrids Swingle citrumelo (Poncirus trifoliata (L). Raf. $\times$ Citrus paradisii Macf.), Carrizo citrange $(C$. sinensis Osb. $\times$ P. trifoliata (L.) Raf.), and Troyer citrange became popular rootstocks for commercial citrus production in Florida and California (2). Although no vector has been reported for CTLV and there are no reports of natural movement of this virus,

Corresponding author: S. Tatineni

E-mail address: Satyanarayana.tatineni@ars.usda.gov

doi:10.1094/PHYTO-99-4-0423

(C) 2009 The American Phytopathological Society the possibility of eventual lateral spread from the large number of dooryard plantings of infected Meyer lemon trees into other citrus cultivars remains a continuous threat to the major citrus producing areas in the United States (16).

The biology of CTLV isolated from Meyer lemon trees has been examined by several groups $(3,5,8,16,21)$; however, the virus has not been characterized molecularly, hindering both the understanding of how CTLV causes disease and the development of management strategies for the citrus industry. CTLV is serologically related to and considered to be an isolate of Apple stem grooving virus (ASGV) (18) and, recently, Hilf (9) used ASGV antiserum to immunocapture CTLV-ML virions, followed by reverse-transcription (RT-PCR) of 600- and 1,100-bp amplicons. The sequence of these two amplicons had 78 to $83 \%$ nucleotide sequence identity with the corresponding sequences of several ASGV strains (9). The genome sequences of ASGV, the type member of the genus Capillovirus of the family Flexiviridae (14); Cherry virus A (CVA), a capillovirus divergent from ASGV; and pear black necrotic leaf spot isolate of ASGV (ASGV-P) have been determined $(10,22,28)$. In addition, two strains of CTLV, one from kumquat (Fortunella spp.) from Taiwan (CTLV-K, GenBank accession no. AY646511) and a lily strain from Japan (CTLV-L) (19), have also been sequenced. Analyses of the genome sequences and their organization suggest that ASGV-P, CTLV-K, and CTLV-L are closely related to ASGV $(19,22)$. The members of the genus Capillovirus are poorly studied molecularly and genetically, and infectious cDNA clones are available only for ASGV (19). However, basic functions have not been assigned 
experimentally to specific open reading frames (ORFs) and the genome expression strategy has not been examined.

Because the CTLV isolate used in the present investigation was initially isolated from Meyer lemon trees, it was designated the Meyer lemon isolate of CTLV (CTLV-ML). Considering the potential threat of CTLV to the U.S. citrus industry, our lack of understanding of its horizontal transmission prompted us to investigate the molecular basis of tatter leaf disease agent. In this article, we report the sequencing of an isolate of CTLV historically associated with Meyer lemon introductions into the United States, its relationship to other viruses in the Capillovirus genus, and the development of infectious cDNA clones.

\section{MATERIALS AND METHODS}

Virus source and maintenance. The CTLV-ML isolate used in this study has been regularly maintained by sequential graft transmission in citrus trees for more than 40 years. CTLV-ML was originally collected from a Meyer lemon tree from a commercial citrus grove near Ruskin, FL in 1964 (5), and was subjected to several single-lesion passages in kidney bean plants before its reintroduction into citrus by mechanical inoculation. Subsequent maintenance of CTLV-ML in Madam vinous sweet orange $(C$. sinensis L.) plants in a greenhouse is as described by Hilf (9).

Virus inoculations. Young flush of CTLV-ML-infected Madam vinous sweet orange or bean plants was extracted with cold $50 \mathrm{mM}$ sodium phosphate buffer, $\mathrm{pH} 7.2$ (1 $\mathrm{g}$ of tissue in $9 \mathrm{ml})$ and inoculated onto carborundum-dusted (600-mesh) primary leaves of bean cultivars.

RNA isolation. Total RNA was isolated from CTLV-ML-infected young leaves of Madam vinous trees or Phaseolus vulgaris cv. Light Red Kidney (LRK) bean plants using Trizol reagent (Invitrogen) as per the manufacturer's instructions. Briefly, 200 to $300 \mathrm{mg}$ of tissue was ground to a fine powder in liquid nitrogen in a mortar and pestle, $1.0 \mathrm{ml}$ of Trizol reagent was then added, and the tissue was ground thoroughly. The extract was transferred to a 2.0-ml Eppendorf tube and incubated for $10 \mathrm{~min}$ at room temperature, and $200 \mu \mathrm{l}$ of chloroform was added and mixed for $20 \mathrm{~s}$. This mixture was incubated at room temperature for $5 \mathrm{~min}$, followed by clarification at $12,000 \times g$ for $15 \mathrm{~min}$ at $4^{\circ} \mathrm{C}$. Isopropanol $(500 \mu \mathrm{l})$ was added to the aqueous phase, mixed thoroughly, and incubated at room temperature for $10 \mathrm{~min}$. Total RNA was pelleted at $12,000 \times g$ for $15 \mathrm{~min}$ at $4{ }^{\circ} \mathrm{C}$, followed by a wash with $70 \%$ ethanol. The RNA pellet was vacuum dried and suspended in 25 to $50 \mu \mathrm{l}$ of sterile water.

RT-PCR amplification of CTLV genome and molecular cloning. Total RNA isolated from systemically infected LRK bean or Madam vinous leaves was used as a template for RT-PCR amplification of the CTLV genome. The oligo (dT) primer TL-2 (5'-GGGCGGCCGCTTTTTTTTTTTTTTTTTT-3', containing an NotI restriction site [in italics]) was used to make the first-strand cDNA using SuperScript II RT (Invitrogen) as per the manufacturer's instructions. Nine microliters $(\approx 2.0 \mu \mathrm{g})$ of total RNA was mixed with $2 \mu \mathrm{l}$ of $5 \mu \mathrm{M}$ TL-2 primer and incubated at $65^{\circ} \mathrm{C}$ for $5 \mathrm{~min}$ and quickly chilled on ice. This was followed by the addition of $4 \mu \mathrm{l}$ of $5 \times$ first-strand buffer, $2 \mu \mathrm{l}$ of $0.1 \mathrm{M}$ dithiothreitol (DTT), $1 \mu \mathrm{l}$ of RNasin $(5 \mathrm{U} / \mu \mathrm{l})$, and water to bring the volume to $19 \mu \mathrm{l}$. The contents of the tube were incubated at $42^{\circ} \mathrm{C}$ for $2 \mathrm{~min}$, followed by addition of $1 \mu \mathrm{l}(200 \mathrm{U})$ of SuperScript II RT and incubation at $42^{\circ} \mathrm{C}$ for an additional $1 \mathrm{~h}$.

The complete genome of CTLV was amplified in a single step using the first-strand cDNA as a template and a pair of oligonucleotides, TL-1 (5'CAGGCATGCATTTAGGTGACACTATAGAATTTAACAGCGCTTAATTTCCGCGC-3', containing the SphI restriction site [italics], followed by the SP6 RNA polymerase promoter [underlined] and 26 nucleotides [nt] of the CTLV 5' end) and TL-2, using SpeedSTAR HS DNA polymerase
(Takara) or Pfu DNA polymerase (Stratagene). CTLV-specific $26 \mathrm{nt}$ in oligonucleotide TL-1 are conserved in CTLV-K and CTLV-L strains. The following conditions were used for PCR amplification in a 100- $\mu$ l reaction: $4 \mu \mathrm{l}$ of cDNA, $1 \times$ buffer with $2 \mathrm{mM}$ $\mathrm{MgCl}_{2}$ (Buffer FB II; Takara), $0.2 \mu \mathrm{M}$ each oligonucleotide (TL-1 and TL-2), $0.2 \mathrm{mM}$ dNTPs, and $5 \mathrm{U}$ of SpeedSTAR HS DNA polymerase or $P f u$ DNA polymerase was amplified for 1 cycle at $94^{\circ} \mathrm{C}$ for $2 \mathrm{~min}$; followed by 8 cycles at $94^{\circ} \mathrm{C}$ for $20 \mathrm{~s}, 58^{\circ} \mathrm{C}$ for $20 \mathrm{~s}$, and $72^{\circ} \mathrm{C}$ for $5 \mathrm{~min}$ (10 min with $P f u$ DNA polymerase); 27 cycles at $94^{\circ} \mathrm{C}$ for $20 \mathrm{~s}, 62^{\circ} \mathrm{C}$ for $20 \mathrm{~s}$, and $72^{\circ} \mathrm{C}$ for $5 \mathrm{~min}$ (10 min with Pfu DNA polymerase); and 1 cycle at $72^{\circ} \mathrm{C}$ for $10 \mathrm{~min}$. PCR product $(5 \mu \mathrm{l})$ was analyzed on a $1.0 \%$ agarose gel in $1 \times$ TAE buffer (40 mM Tris-acetate, $\mathrm{pH} 8.3$, and $1.0 \mathrm{mM}$ EDTA) and DNA bands were visualized by ethidium bromide staining. Genome-sized PCR products were digested with NotI restriction enzyme and cloned into a modified pUC119 between $H p a \mathrm{I}$ and NotI restriction sites.

Sequencing of CTLV cDNAs and sequence analyses. Sequencing of CTLV cDNA clones was carried out at the University of Florida ICBR Core DNA Sequencing Facility using an Applied Biosystems 3730 model sequencer. Both strands of full-length cDNA clones of pCTLV (pCTLV) were sequenced by the primer walking method. The sequence of pCTLV-81, a full-length cDNA clone of CTLV-ML, was deposited in GenBank with the accession number EU553489. Pairwise alignment of individual sequences to assemble a full-length CTLV genome and sequence comparisons of CTLV-ML with other capilloviruses was carried out using ALIGN or LALIGN programs of online analysis tools (http://molbiol-tools.ca). Multiple sequence alignments were performed with ClustalW program (25) and the MEGA 3.1 analysis package (11) was used to perform phylogenetic analysis using the neighbor-joining (NJ) method with 1,000 bootstrap replicates as the test of phylogeny.

$5^{\prime}$ Rapid amplification of cDNA ends of the genomic RNA. The exact $5^{\prime}$ end sequence of CTLV-ML was determined using dsRNA-enriched preparation as the template with the 5' rapid amplification of cDNA ends (RACE) system (Invitrogen). Firststrand cDNA synthesis was performed using the gene-specific primer 1 (GSP1, 5'-ATTACGTTCAAGGCATTGGTCTCTGAG3', complementary to nucleotides 524 to 498 of CTLV-ML) and unincorporated nucleotides and GSP1 primer were removed using sodium iodide, followed by column purification as per the instructions of the kit. The $3^{\prime}$ end of the purified first-strand cDNA was ' $\mathrm{C}$ ' tailed using terminal deoxynucleotidyl transferase (TdT), and CTLV-ML-specific DNA was amplified using GSP2 (5'-ACCAATCACTCTATCTCTGAATGAG-3', complementary to nucleotides 497 to 473 of CTLV-ML) and abridged anchor primer (supplied with kit) using Taq DNA polymerase $(2.5 \mathrm{U})$ for 1 cycle at $94^{\circ} \mathrm{C}$ for $2 \mathrm{~min}$; followed by 40 cycles at $94^{\circ} \mathrm{C}$ for $20 \mathrm{~s}, 55^{\circ} \mathrm{C}$ for $20 \mathrm{~s}$, and $72^{\circ} \mathrm{C}$ for $1 \mathrm{~min}$; and one cycle at $72^{\circ} \mathrm{C}$ for $10 \mathrm{~min}$. The 5' RACE PCR product was ligated into pGEM-Teasy vector (Promega Corp.) and the inserts were sequenced at the ICBR Core DNA Sequencing Laboratory, University of Florida, Gainesville.

In vitro transcription and inoculation of plants. The in vitro transcription reaction was carried out in a $30-\mu$ l volume consisting of $1.0 \mu \mathrm{g}$ of NotI-linearized plasmid DNA, $40 \mathrm{mM}$ Tris- $\mathrm{HCl}(\mathrm{pH}$ 7.9), $20 \mathrm{mM}$ DTT, $8.5 \mathrm{mM} \mathrm{MgCl} 2,2 \mathrm{mM}$ spermidine, $1.2 \mathrm{mM}$ concentration each of ATP, CTP, UTP, and cap analog $\left(\mathrm{m}^{7} \mathrm{G}\left[5^{\prime}\right] \mathrm{ppp}\left[5^{\prime}\right] \mathrm{G}\right)$ (Epicentre Technologies), $0.048 \mathrm{mM}$ GTP, $20 \mathrm{U}$ of rRNasin ribonuclease inhibitor (Promega Corp.), and $25 \mathrm{U}$ of SP6 RNA polymerase (Epicentre Technologies). The transcription reaction was incubated for $15 \mathrm{~min}$ at $37^{\circ} \mathrm{C}$, followed by an increase of GTP concentration to $0.5 \mathrm{mM}$ and an additional incubation for $2 \mathrm{~h}$ at $37^{\circ} \mathrm{C}$.

A freshly prepared $30-\mu$ l transcription reaction was diluted to $50 \mu \mathrm{l}$ with RNase-free water and mixed with $50 \mu \mathrm{l}$ of $2 \%$ sodium pyrophosphate containing bentonite at $2 \mathrm{mg} / \mathrm{ml}$, and $20 \mu \mathrm{l}$ of the 
mixture was inoculated onto carborundum-dusted primary leaves of LRK bean plants. Transcript-inoculated bean plants were incubated at $22^{\circ} \mathrm{C}$ in a growth chamber for symptom development.

Northern blot hybridization of CTLV RNAs. Positivestranded RNA-specific probe was synthesized from a 5' 643-bp DNA fragment amplified with oligonucleotides TL-3 (5'-AAATTTAACAGCGCTTAATTTCCGCGC, corresponding to nucleotides 1 to 27) and TL-5 [5'-CCTTAATACGACTCACTATAGGGAACACAGTTGTCGCAACAAC, complementary to nucleotides 643 to 621 [in italics] with T7 RNA polymerase promoter sequence [underlined]) using the recombinant pCTLV-81 as a template. The negative-stranded RNA probe, which is specific to the positive-stranded RNA, was synthesized from a gene-cleaned PCR product template using T7 RNA polymerase and nucleotides containing the digoxigenin-labeled UTP as per the manufacturer's instructions (Roche).

Total RNA was separated in a $1.0 \%$ formaldehyde-formamide agarose gel and transferred onto a nylon membrane using electrotransfer (20). Prehybridization at $65^{\circ} \mathrm{C}$ for 1 to $2 \mathrm{~h}$ and hybridization at $65^{\circ} \mathrm{C}$ for overnight were carried out in a hybridization incubator with a positive-stranded RNA-specific probe specific to the 5' end of the genomic RNA. Nylon membranes were washed with $2 \times \mathrm{SSC}(1 \times \mathrm{SSC}$ is $0.15 \mathrm{M} \mathrm{NaCl}$ plus $0.015 \mathrm{M}$ sodium citrate) containing $0.1 \%$ sodium dodecyl sulfate (SDS) for $10 \mathrm{~min}$ at room temperature, followed by two washes with $0.1 \times \mathrm{SSC}$ containing $0.1 \%$ SDS for $30 \mathrm{~min}$ at $65^{\circ} \mathrm{C}$, and the membranes were developed for image capture on X-ray film as per the manufacturer's instructions (Roche).

\section{RESULTS}

RT-PCR amplification and molecular cloning of CTLV-ML genomic RNA. Amplification of the entire CTLV-ML genomic RNA in a single step with oligonucelotides specific to the $5^{\prime}$ and $3^{\prime}$ ends of the genomic RNA (TL-1 and TL-2) using cDNA synthesized from total RNA primed with TL-2 (Fig. 1) was successful only with SpeedSTAR HS DNA polymerase. Only less than full-length $(2.0$ to $4.0 \mathrm{~kb})$ fragments were amplified using the same conditions with Pfu, Vent, or Taq DNA polymerases (data not shown). To facilitate cloning of the PCR product into a bluntend (HpaI)- and NotI-digested vector, we reamplified the fulllength CTLV cDNA using the gel-isolated SpeedSTAR RT-PCR product as a template and $P f u$ DNA polymerase to obtain bluntended PCR products (SpeedSTAR HS DNA polymerase produces 3' A-overhangs). The Pfu PCR product was digested with NotI restriction enzyme and ligated into a modified pUC119 between HpaI and NotI restriction sites. A large number of recombinant colonies were obtained that contained inserts of $6.5 \mathrm{kbp}$. Eighteen independent clones with CTLV cDNA as inserts were selected, and two independent clones, pCTLV-66 and pCTLV-81, were used for sequencing the genome.

Sequence analyses of CTLV-ML genomic RNA. The CTLVML genome is 6,495 nt long, excluding the $3^{\prime}$ poly (A) tail, with a large ORF (ORF1) that spans most of the genome and a second ORF (ORF2) positioned within the $3^{\prime}$ portion of ORF1 in a different reading frame (Fig. 1). ORF1 (nucleotides 37 to 6,354) putatively encodes a polyprotein of 2,105 amino acids (aa) with a proposed molecular weight of $\approx 242 \mathrm{kDa}$ (p242), which is similar to other capilloviruses, and consists of methyltransferase-like, papain-like protease, helicase-like, and RdRp-like domains, as well as the coat protein (CP). The $\mathrm{CP}$ encodes a putative $27-\mathrm{kDa}$ protein of 237 aa, located in the C-terminal region of ORF1 polyprotein (nucleotides 5,641 to 6,354), contiguous with replicationassociated proteins. The location of $\mathrm{CP}$ was identified based on sequence homology with ASGV strains $(19,22,28)$. ORF2 (nucleotides 4,788 to 5,750 ) encodes a $36-\mathrm{kDa}$ protein with similarities to the $30-\mathrm{kDa}$ superfamily of cell-to-cell movement proteins (MP) (15).

The sequences of the two independent cDNA clones were $99.7 \%$ identical, differing at only 13 positions. The observed nucleotide differences resulted in 11 aa changes in ORF1 (5 changes resulted in substitution of different amino acid residues and 6 resulted in substitution of similar residues), and 2 changes occurred in ORF2, resulting in substitution of different residues (Table 1). Sequence changes were not observed in the CP coding region.

The CTLV-ML polyprotein, excluding the CP sequence, possesses $28,87,87,85$, and $84 \%$ identity with the corresponding

TABLE 1. Deduced amino acid changes between the genome sequence of two independent full-length cDNA clones (pCTLV-66 and pCTLV-81) of Citrus tatter leaf virus from Meyer lemon (CTLV-ML)

\begin{tabular}{lcc}
\hline ORF $^{\text {a }}$, amino acid position & pCTLV-66 & pCTLV-81 \\
\hline ORF1, 208 & $F^{\mathrm{b}}$ & $L$ \\
ORF1, 331 & $T$ & $A$ \\
ORF1, 537 & $\mathbf{G}$ & $\mathbf{E}$ \\
ORF1, 589 & $\mathbf{S}$ & $\mathbf{P}$ \\
ORF1, 746 & $T$ & $A$ \\
ORF1, 775 & $T$ & $A$ \\
ORF1, 958 & $L$ & $F$ \\
ORF1, 1230 & $\mathbf{S}$ & $\mathbf{L}$ \\
ORF1, 1311 & $A$ & $V$ \\
ORF1, 1691 & $\mathbf{R}$ & $\mathbf{G}$ \\
ORF1, 1704 & $\mathbf{R}$ & $\mathbf{G}$ \\
ORF2, 117 & $\mathbf{E}$ & $\mathbf{G}$ \\
ORF2, 120 & $\mathbf{E}$ & $\mathbf{G}$
\end{tabular}

a Open reading frame $(\mathrm{ORF})$.

b Amino acids in italics, change to a similar amino acid; amino acids in bold, change to a different amino acid.
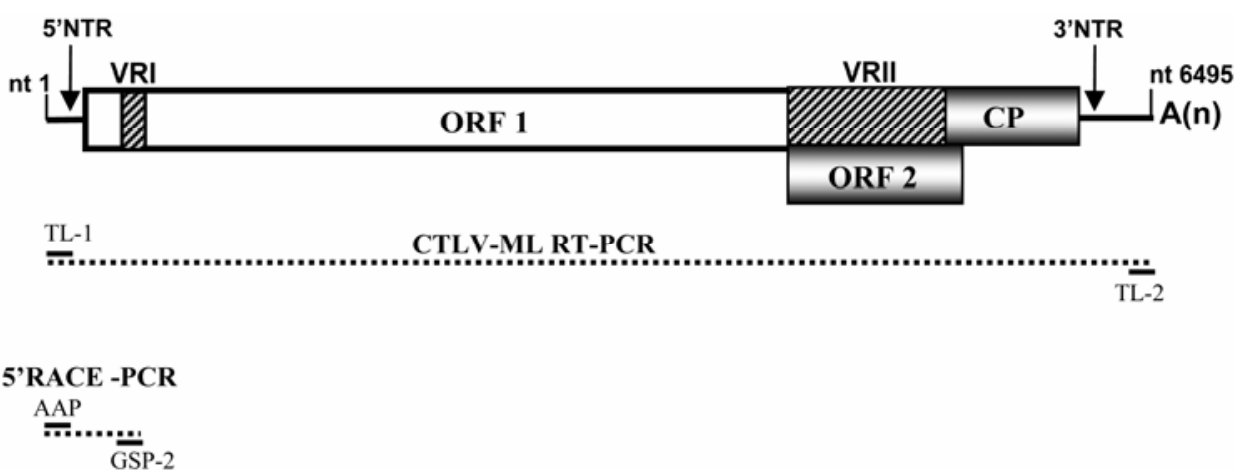

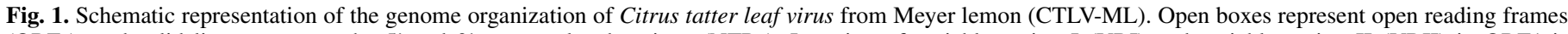

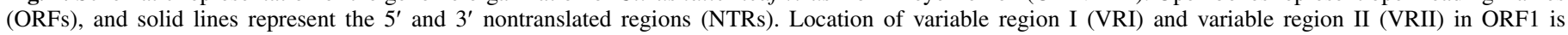

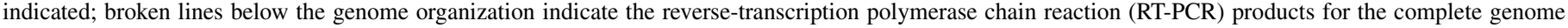

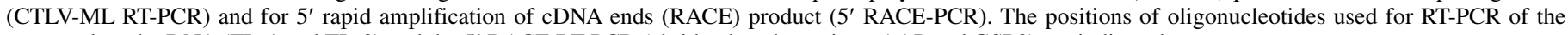
genome-length cDNA (TL-1 and TL-2) and the 5' RACE RT-PCR (abridged anchor primer AAP and GSP2) are indicated. 
polyproteins of CVA, ASGV, CTLV-K, CTLV-L, and ASGV-P, respectively (Table 2). The amino acid sequence identities of the CTLV-ML MP and CP were 94 to 95 and 94 to $96 \%$, respectively, when compared with the MPs and CPs of ASGV, CTLV-K, CTLV-L, and ASGV-P, indicating a high degree of sequence conservation. In contrast, CTLV-ML MP and CP showed only 23 and $27 \%$ identity, respectively, with that of CVA (Table 2).

We performed both maximum parsimony and NJ phylogenetic analysis with the amino acid sequences of the indicated capilloviruses and obtained similar tree topologies with both methods; therefore, we present only the results of NJ analysis. Because NJ analysis of the CTLV-ML p242, MP, and CP produced trees with similar topology, only the results of analysis of CTLV-ML p242 and the analogous proteins are presented as an unrooted tree (Fig. 2). As expected from the calculated amino acid identities of $\mathrm{p} 242$, CTLV-ML grouped with ASGV, CTLV-K, CTLV-L, and ASGV-P in a well-supported cluster apart from CVA, which terminated on a separate branch (Fig. 2). Phylogenetic analysis suggests that CTLV-ML, CTLV-K, CTLV-L, and ASGV share a common ancestor, which diverged subsequent to their divergence from ASGV-P. Nonetheless, pairwise comparisons and phylogenetic analysis indicate a close genetic relationship among ASGV, CTLV-L, CTLV$\mathrm{K}$, CTLV-ML, and ASGV-P, which all have a common recent ancestor that is divergent from CVA (Table 2; Fig. 2).

Even though the CTLV-ML p242 possess 84 to $87 \%$ aa identity with other capilloviruses (except CVA), it contained two variable regions between amino acids 532 and 570 (variable region I) and 1,583 and 1,868 (variable region II) that showed only 15 to 18 and 56 to $62 \%$ identity, respectively, with ASGV, CTLV-K, CTLV-L, and ASGV-P (Table 3; Fig. 3). Multiple alignment of amino acids of two variable regions showed no conserved amino acid in variable region I and fewer conserved amino acids in variable region II between CTLV-ML and other capilloviruses (Fig. 3 ). Because the p242 sequences of CTLV-ML and CVA differ by $72 \%$, we failed to locate the corresponding variable regions in the CVA polyprotein. Interestingly, the nucleotide sequence encoding variable region II of ORF1 also encodes a highly conserved ORF2 in a different reading frame (Fig. 1). There is no significant similarity of variable regions with other reported protein sequences in GenBank.

The 5' nontranslated region (NTR) is $36 \mathrm{nt}$, which is highly conserved (94 to 97\%) with corresponding sequences of ASGV, CTLV-K, CTLV-L, and ASGV-P, and 50\% identity with that of CVA. The $3^{\prime}$ NTR is 141 nt, excluding the poly (A) tail. The $3^{\prime}$ NTR possesses 87 to $91 \%$ sequence identity with ASGV, CTLVK, CTLV-L, and ASGV-P and only $19 \%$ identity with the corresponding region of CVA.

Determination of the 5' end of the CTLV-ML genomic RNA. Because the $5^{\prime}$ end sequence play a crucial role in replication of a virus, we decided to determine the exact $5^{\prime}$ end sequence of CTLV-ML to further develop infectious cDNA clone. The sequences of the CTLV-K (GenBank accession no. AY646511) and CTLV-L (19) 5' ends start with two As, whereas that of ASGV starts with three As (28). To determine the exact 5' end sequence of CTLV-ML, we amplified the 5' region with 5' RACE system and cloned the PCR product (Fig. 1). We sequenced $155^{\prime}$ RACE clones and observed that all 15 clones contained three As at their 5 ' end, with no other ambiguities.

Optimizing conditions for systemic infection of CTLV-ML in an herbaceous host. In order to examine the infectivity of in vitro transcripts from cDNA clones, we optimized conditions for systemic infection of CTLV-ML in a herbaceous host. Garnsey (7) reported that CTLV-ML induced local necrotic lesions, followed by occasional systemic symptoms on $P$. vulgaris plants. In the first experiment, we inoculated LRK bean primary leaves with CTLV-ML and incubated them in a 24 to $26^{\circ} \mathrm{C}$ growth room. LRK bean plants produced few necrotic local lesions at 2 to 4 days postinoculation (dpi), followed by systemic chlorotic spots, veinal necrosis, and leaf deformation symptoms developed on 90 to $100 \%$ of plants by 10 to 15 dpi (Fig. 4). However, we failed to

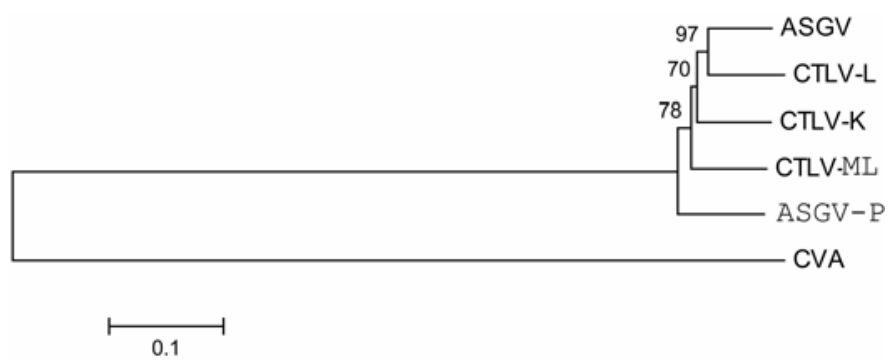

Fig. 2. Unrooted phylogenetic tree derived from the amino acid sequences of open reading frame $(\mathrm{ORF}) 1$ of Citrus tatter leaf virus from Meyer lemon (CTLV-ML) and other available capilloviruses. Phylogenetic tree was constructed by the neighbor-joining method with 1,000 bootstrap replicates, and bootstrap support is indicated at branch points. The bar represents the number of amino acid replacements per site. Note that CTLV-ML is clustered with Apple stem grooving virus (ASGV), CTLV from kumquat (CTLV-K), CTLV from lily (CTLV-L), and pear black necrotic leaf spot isolate of ASGV (ASGV-P), whereas Cherry virus A (CVA) formed a separate branch. GenBank accession numbers of capilloviruses used in phylogenetic tree analysis were as shown in Table 2.

TABLE 3. Amino acid identities (\%) of variable region I (above diagonal) and variable region II (below diagonal) of capilloviruses ${ }^{\mathrm{a}}$

\begin{tabular}{lccccc}
\hline Virus & CTLV-ML & ASGV & CTLV-K & CTLV-L & ASGV-P \\
\hline CTLV-ML & 100 & 15 & 15 & 18 & 15 \\
ASGV & 56 & 100 & 13 & 23 & 15 \\
CTLV-K & 62 & 60 & 100 & 15 & 21 \\
CTLV-L & 57 & 56 & 53 & 100 & 10 \\
ASGV-P & 58 & 58 & 60 & 53 & 100 \\
\hline
\end{tabular}

a Viruses: Citrus tatter leaf virus from Meyer lemon (CTLV-ML), Apple stem grooving virus (ASGV), CTLV from kumquat (CTLV-K), CTLV from lily (CTLV-L), and pear black necrotic leaf spot isolate of ASGV (ASGV-P). GenBank accession numbers for ASGV, CTLV-K, CTLV-L, ASGV-P, and CVA are NC 001749, AY646511, D16681, AY596172, and NC003689, respectively. Open reading frame 1 of Cherry virus $A$ is highly variable with other members of capilloviruses; thus, CVA was not included for variable region analysis.

TABLE 2. Amino acid identities (\%) of open reading frame (ORF)1 polyprotein (above diagonal), putative coat protein (CP) (below diagonal), and movement protein (MP) (in parenthesis, below diagonal) of capilloviruses ${ }^{\mathrm{a}}$

\begin{tabular}{|c|c|c|c|c|c|c|}
\hline Virus & CTLV-ML & ASGV & CTLV-K & CTLV-L & ASGV-P & CVA \\
\hline CTLV-ML & 100 & 87 & 87 & 85 & 84 & 28 \\
\hline ASGV & $95(95)$ & 100 & 87 & 87 & 85 & 28 \\
\hline CTLV-K & 94 (95) & $95(95)$ & 100 & 86 & 85 & 28 \\
\hline ASGV-P & $95(94)$ & $95(92)$ & 94 (93) & 97 (93) & 100 & 29 \\
\hline CVA & $27(23)$ & $28(25)$ & $26(24)$ & $26(23)$ & $26(23)$ & 100 \\
\hline
\end{tabular}

a Viruses: Citrus tatter leaf virus from Meyer lemon (CTLV-ML), Apple stem grooving virus (ASGV), CTLV from kumquat (CTLV-K), CTLV from lily (CTLV-L), pear black necrotic leaf spot isolate of ASGV (ASGV-P), and Cherry virus A (CVA). GenBank accession numbers for ASGV, CTLV-K, CTLV-L, ASGV-P, and CVA are NC 001749, AY646511, D16681, AY596172, and NC003689, respectively. 


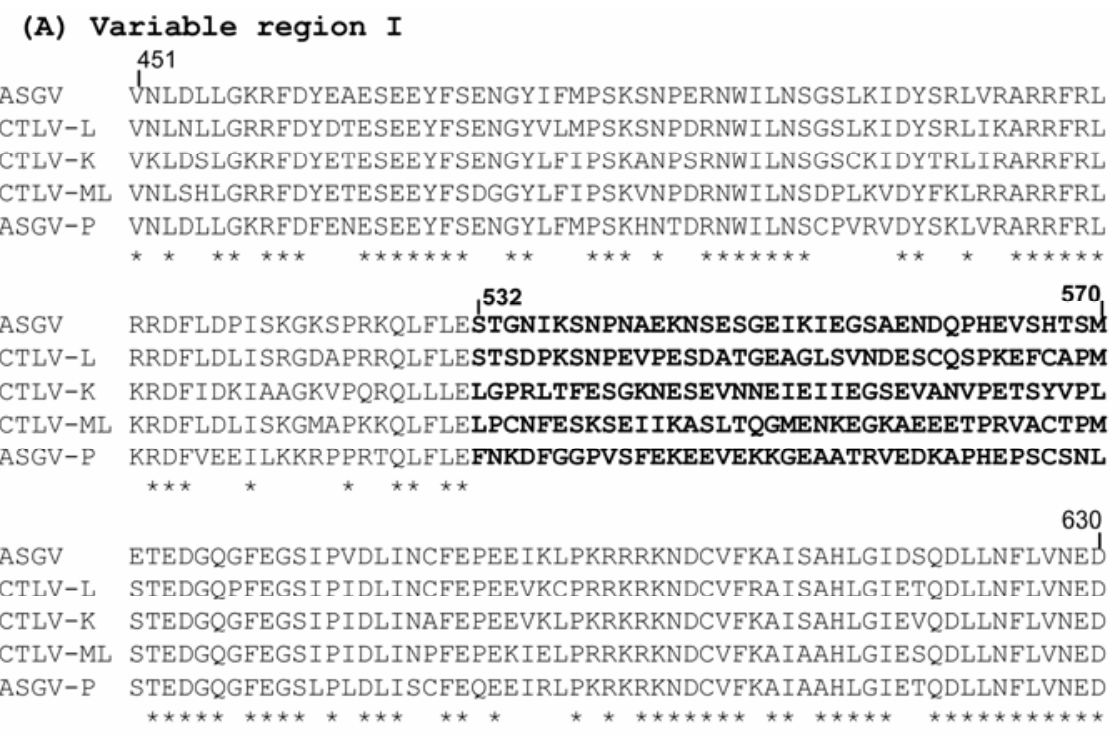

(B) Variable Region II

\begin{tabular}{|c|c|}
\hline & 1541 \\
\hline & YTILKEEDFEYHYLVIREFVKNSKLLTGLSKSLIFEIGEGIGAEWLSSMSTISSRRSSQL \\
\hline & TTILEEDFEYHYLVIRFFVKNSKLLTGLSKSLIFEIGEGIGSEWQSSMSTTSSKRLSQQ \\
\hline 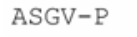 & TILKEEDFEYHYLVIRFFVKNSKLLTGLSKSLIFEIGEGIGSEWQLSMSTTSSKRLNQQ \\
\hline $\mathrm{SC}$ & TILKEEDFEYHYLVIRFFVRNSKLLTGLSKSLIFEIGEGIGSKWLSSTSTASSRRSNLQ \\
\hline \multirow[t]{2}{*}{ CTLV-L } & TILKEEDFEYHYLVIRFFVRNSKLLTGLSKSLIFEIGEGIGSEWRSSMSTISSRRSSQQ \\
\hline & 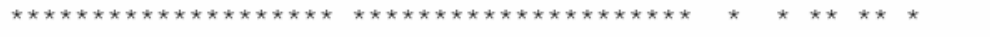 \\
\hline 11 & SKLTPSPHLNCTKMQPFLSQTYSTASKGLSQMSKFLQDQGMDSYCLTLNSLMTLRLTPL \\
\hline ML & LKLMRSPPLSCTKMQPFLSQMCSTASKGLNQTLRCHPGLAMDWCFQISNSLMTLKSTPL \\
\hline & SRLMPSRHLNFIKMQPFSSQMFSIASNDLNQMSKCLKVRVMDSCCPTSSCLMTQKLTPL \\
\hline SGV & SKLMLSRPQSFTRMQPFSNQTCLIASKGLNQTSRFPLDLVTASSCLISNCLMTPKLIQS \\
\hline \multirow[t]{2}{*}{ CTLV-L } & SRLTQSHPQNFTKMQPFSSRMCSIVSKDLSQMSKFPPGLGMDWSCQISSCLMTLKSTQS \\
\hline & 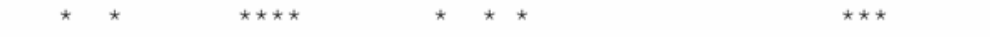 \\
\hline K & RRAINTNIYIMESSWWESKPCCPTLEEWKGELLYMMGLVWIQKGVTSVLICLNSSLTVV \\
\hline AL & KRVTNTSTYTMESSWLESKQCCQTLEEWRGESSCMTELAWTQGEATSVRICSNLSPTVV \\
\hline SC & RRATSTNTYIMELFLLASKQCCPTSGEWKGGSLYMTVPVWTQKEVIYVPTYSDLSLTAV \\
\hline V & GRKATSTNTYTMESSWLGSKQCCQTLEAWKGESLYMMEPAWIRKEATFARIFSSLSLTVA \\
\hline \multirow[t]{2}{*}{ CTLV-L } & EKRATSTSTCITESFWLESKQCCQTSEVWKEGSLCMTEPVLIRKKAIYARICLSLSLTAV \\
\hline & 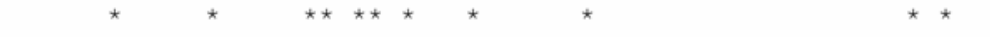 \\
\hline & DLSTVFQQLMQIWLKDVGSEWILIVHSMNRTRNCLLLTLGLHTDVSTQQGFSKLRL \\
\hline IL & ILDLDLNTVFPQLTLIWQKDSGLEWISTAHSMNRTQNCLLLILGLLTDVSILLDSLKQKL \\
\hline & PLDSDQNIAYLQLMLIWQKGSGSEWILTVHNTNRTQSCLLLTLELHTGVSTQLDSWKPKQ \\
\hline $\mathrm{S}$ & 'LVSGQSTVCLPQTQIWPKGLDFVWTLIVHNMNRTLSCLLLTLELHTDASTLQGEWKPKL \\
\hline \multirow[t]{2}{*}{ CTLV-L } & SVLDLNTAYPPQMPTWRRDSDFVWTFTAHSMNRTLSCLLLTLVWPTDVLIQPASWKPRL \\
\hline & 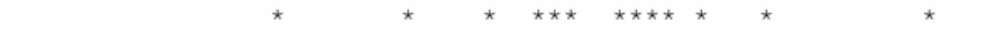 \\
\hline K & IIQGGLHRLSAAVRHSSLTKKSSWPSWITNPRCFWRKVHQMCMLKRDCLEATKFEDI \\
\hline ML & VIQGGLRKLSAVVKHSNLMKRSKWPSWITNPRCFWRRVHQMCTLKKDYLEVTKLEGHVLF \\
\hline $\mathrm{P}$ & RCFWRKVHRMCILKKECSEGTRSGGRALS \\
\hline 5 & AIQDGLHRQSAAVKHLNSMRKSRWPSWIADPRCFWKKVHQTCTLKR \\
\hline \multirow[t]{3}{*}{ CTLV-L } & PTQGGPRRLLVAVRHSDLMKKLKWQFWTISLHYFWRKVFQMFILKRGCSEVTRLEGHARF \\
\hline & 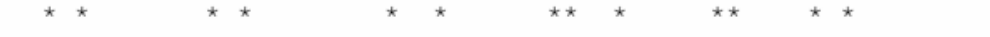 \\
\hline & $1^{1868}$ \\
\hline$-\mathrm{K}$ & LPKGDQTQSCKKREDLGPSQLELKDLGKMSLEDVLQQARRHRVGV \\
\hline ML & LQKGGQTQNYRKREDLGPSQQELKDSERMSLEDVLQQARRHRVGVYLWKTHID \\
\hline $\mathrm{P}$ & LPKGGQTQGQKKREDLGPSQRGLKDLGKMSLEDVLQLARRHRVGVYLWKTQI \\
\hline 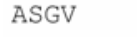 & PLKGGQTQGCKKREDLGPSRLELKDLEKMSLEDVLQQARRHRVGVYLWKTHIDPAKELLT \\
\hline$-\mathrm{L}$ & QKGGQTRNRRKREDLGPSQLELKDSEKMSLEDVLQQARRHRVGVYLWKTH I DPAKELLT \\
\hline & 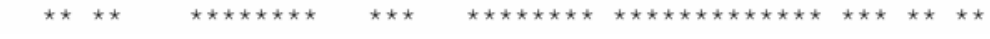 \\
\hline
\end{tabular}

Fig. 3. Multiple alignment of amino acid sequences of the variable region I (VRI) (A) and variable region II (VRII) (B) of the open reading frame (ORF)1encoded protein of Citrus tatter leaf virus from Meyer lemon (CTLV-ML), CTLV from kumquat (CTLV-K), pear black necrotic leaf spot isolate of Apple stem grooving virus (ASGV-P), ASGV, and CTLV from lily (CTLV-L). The numbers in bold indicate the coordinates of the amino acid positions of VRI and VRII in ORF1 of capillovirus sequences. The location of variable regions (in bold) was conserved in all sequences used for alignment. Amino acid sequence that is conserved on either side of the VR1 and VRII used for multiple alignment to show the sequence homology contrast between the variable regions and adjacent amino acids. Asterisks indicate identical amino acids in all sequences. 
reproduce similar systemic symptoms in LRK bean plants in subsequent experiments 3 to 4 months later, which prompted us to examine whether variation in temperature or the bean cultivar affected systemic infection of CTLV-ML.

We inoculated LRK, Frijoles Colorados Red Kidney bean (FCRK), and pinto bean cultivars of $P$. vulgaris with the wild-type virus and incubated them at 19,22 , and $32^{\circ} \mathrm{C}$ in growth chambers with a 16-h photoperiod to examine whether temperature affected systemic infection. Inoculated plants were also kept in a growth room $\left(24\right.$ to $\left.26^{\circ} \mathrm{C}\right)$, a greenhouse $\left(26\right.$ to $\left.34^{\circ} \mathrm{C}\right)$, and a temperaturecontrolled greenhouse $\left(24\right.$ to $29^{\circ} \mathrm{C}$ ). LRK and FCRK bean plants at incubation temperatures $>22^{\circ} \mathrm{C}$ produced a large number of local necrotic lesions at 2 to $4 \mathrm{dpi}$, with no or few plants developing systemic symptoms by 10 to 15 dpi (Table 4). LRK and FCRK bean plants incubated at 19 and $22^{\circ} \mathrm{C}$ produced fewer local necrotic lesions, yet showed $100 \%$ systemic symptoms such as leaf chlorosis, necrotic spots, mosaic, and leaf deformation symp- toms by 10 to 15 dpi (Fig. 4). Pinto bean plants incubated at 19 and $22^{\circ} \mathrm{C}$ and in a greenhouse with temperatures-maintained at 24 to $29^{\circ} \mathrm{C}$ produced a large number of local necrotic lesions with no systemic symptoms at $15 \mathrm{dpi}$ and only a few necrotic lesions at higher temperatures $\left(26\right.$ to $\left.34^{\circ} \mathrm{C}\right)$ (Table 4). Our data indicate that the largest number of systemic infections of $\operatorname{LRK}(5 / 5,9 / 9)$ and FCRK $(4 / 4,4 / 4)$ with CTLV-ML occurred at 19 and $22^{\circ} \mathrm{C}$, with that number drastically reduced at temperatures $>22^{\circ} \mathrm{C}$. Thus, in subsequent experiments, bean plants inoculated with the wildtype virus and in-vitro-generated transcripts from cDNA clones were incubated at $22^{\circ} \mathrm{C}$ for symptom development.

In vitro transcripts from cDNA clones of CTLV-ML are infectious. The 5' RACE data suggest that the 5' end of CTLVML starts with three As, whereas our cDNA clones used for sequencing contained two As derived from the primer. Therefore, the 5' ends of all 18 independent full-length cDNA clones (obtained earlier) were repaired with oligonucleotide TL-1a (5'CAGGCAT-

\section{A}

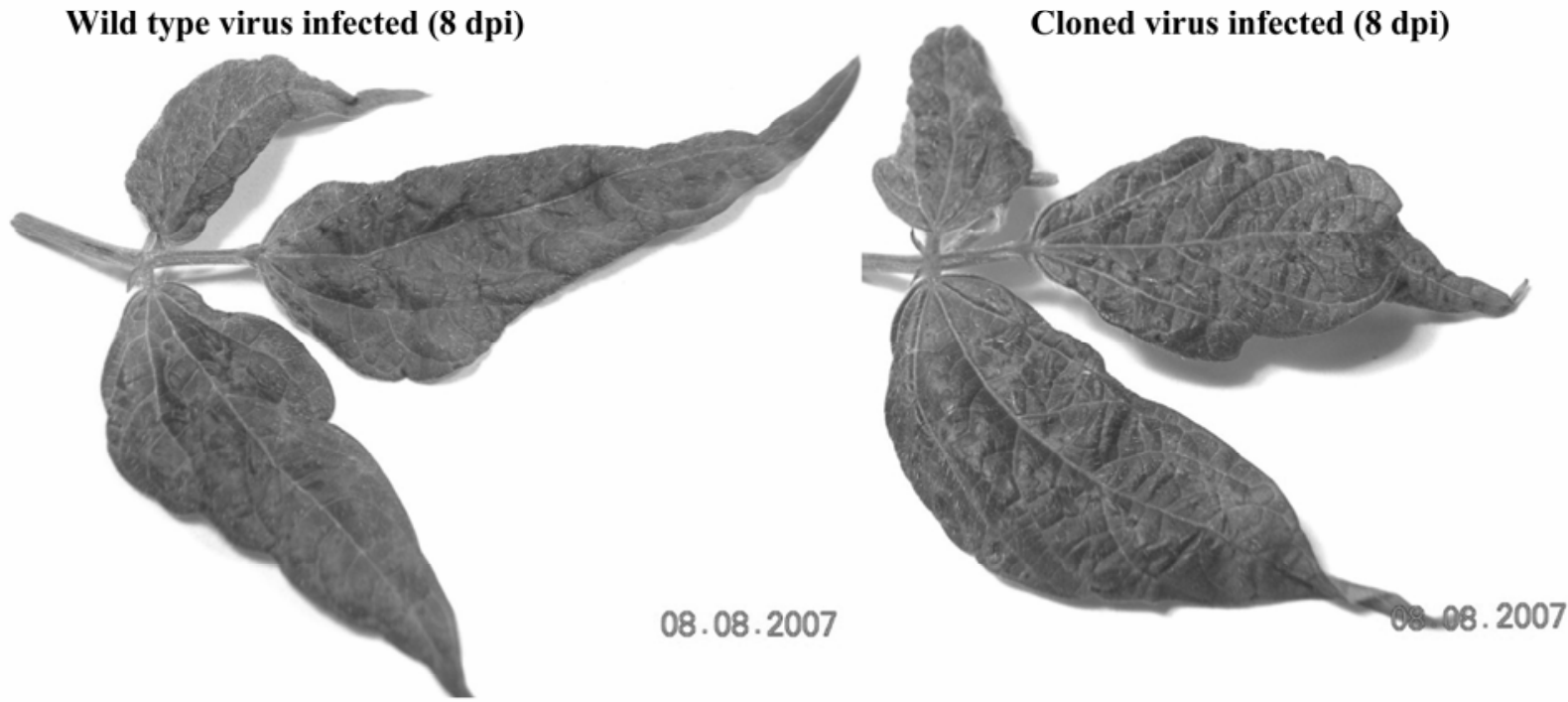

B
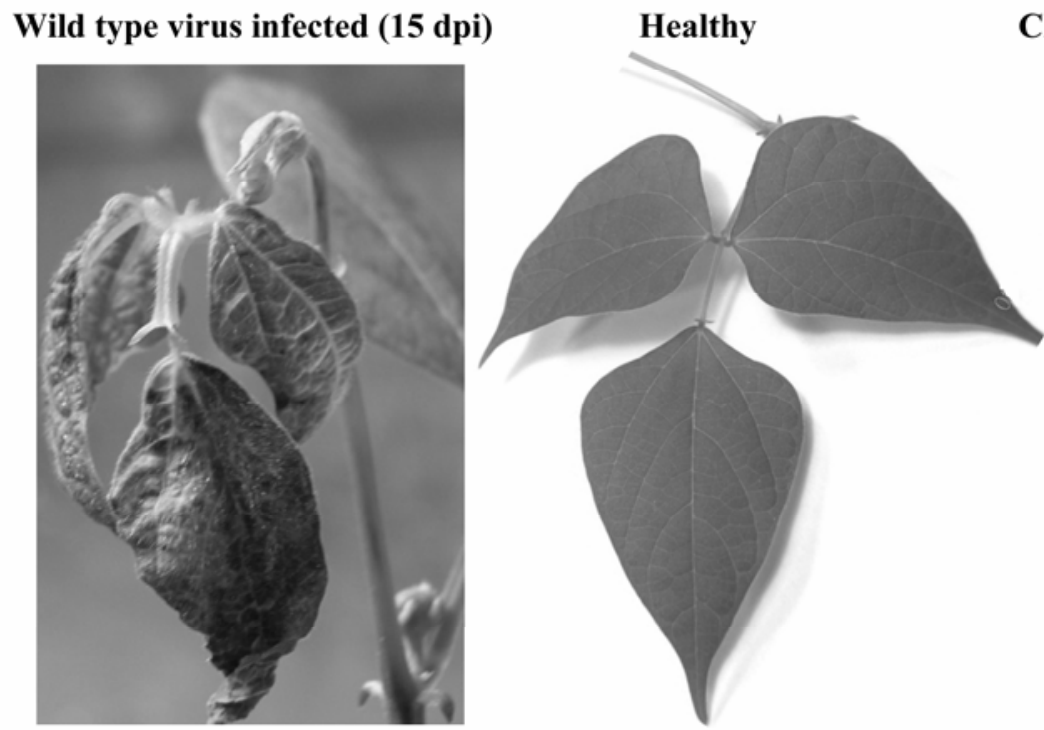

Cloned virus infected (15 dpi)

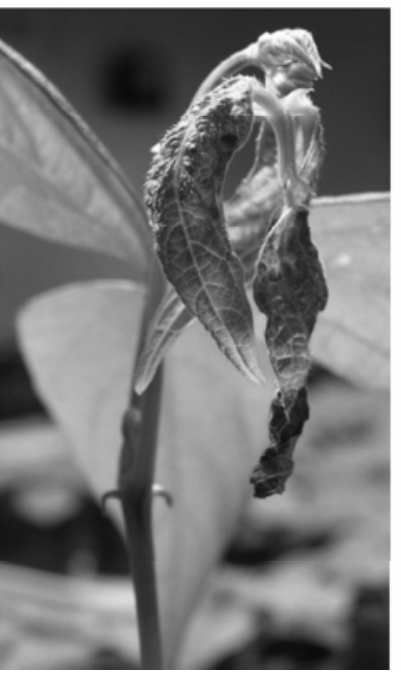

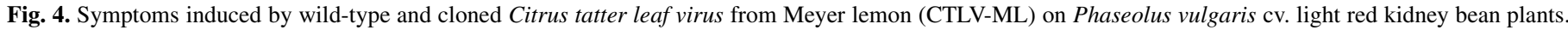

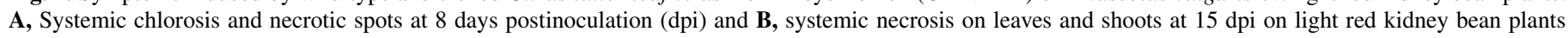
induced by wild-type virus and in vitro transcripts from pCTLV-81. Plants were incubated in a growth chamber at $22^{\circ} \mathrm{C}$. 
GCATTTAGGTGACACTATAGAAATTTAACAGCGCTTAATTTCCGCGC-3'), which contains three As (bold-faced italics) after the SP6 RNA polymerase promoter (underlined). Full-length cDNAs of CTLV-ML were amplified with $P f u$ DNA polymerase from the original 18 independent cDNA clones using oligonucleotides, TL-1a and TL-2, and the amplified PCR products were digested with NotI restriction enzyme and ligated into a modified pUC119 between HpaI and NotI restriction sites. Capped in vitro transcripts were generated and inoculated onto primary leaves of each of four to five LRK bean plants, incubated at $22^{\circ} \mathrm{C}$, and evaluated periodically for symptom development. In vitro transcripts from seven cDNA clones elicited systemic infections in at least one of the inoculated LRK plants at 10 to $15 \mathrm{dpi}$, whereas in vitro transcripts from $11 \mathrm{cDNA}$ clones failed to produce symptoms on LRK bean plants (Table 5).

Transcript-inoculated bean plants produced systemic mosaic, veinal chlorosis, and leaf cupping symptoms at 10 to $15 \mathrm{dpi}$, similar to that of the wild-type virus (Fig. 4). Total RNA extracted from systemically infected leaves of LRK plants inoculated with transcripts from pCTLV-66 and pCTLV-81 was analyzed by northern blot hybridization using a $5^{\prime}$ positive-stranded RNAspecific probe and by RT-PCR using CTLV-ML-specific primers. The 5' positive-stranded RNA-specific probe hybridized strongly with a genome-sized RNA similar to the total RNA from plants inoculated with the wild-type virus; no hybridization signal was detected with total RNA extracted from healthy controls (Fig. 5A). Additionally, a pair of oligonucleotides, TL-3 and TL-4 (5'TTCAATTGGGAACACAGTTGTCGCAAC, complementary to nucleotides 650 to 624) were used for RT-PCR analysis of total RNA extracted from in vitro transcript-inoculated bean plants, and these primers amplified a specific PCR product of the expected size (Fig. 5B). This RT-PCR product was sequenced with CTLV-ML-specific primer (TL-3) and the resulting sequence showed $100 \%$ identity with sequence of the wild-type virus. Collectively, these data demonstrate that in vitro transcripts from cDNA clones of CTLV-ML were, indeed, infectious in a manner similar to that of the wild-type virus.

\section{DISCUSSION}

The ability of CTLV to induce a scion/rootstock bud union incompatibility of citrus trees grafted on trifoliate orange rootstock, together with the predominance of trifoliate orange-derived rootstocks in California and Florida, indicates the potential economic impact CTLV could have in current production systems. As a first step toward understanding the molecular basis of CTLVinduced diseases, we sequenced the genome of CTLV historically associated with Meyer lemon trees (CTLV-ML) and generated infectious in vitro transcripts from genomic cDNA clones, which induced systemic symptoms in LRK bean plants similar to that of the wild-type virus.

The genome of CTLV-ML is 6,495 nt, the same size as that of ASGV (28), CTLV-K (GenBank accession no. AY646511),
CTLV-L (19), and ASGV-P (22). However, the CTLV-ML genome is much smaller than that of CVA (6,495 versus 7,383 nt), another species in the Capillovirus genus (10). CTLV-ML has high sequence identity with ASGV, CTLV-K, CTLV-L, and ASGV-P in ORF1 (84 to 87\%), and MP and CP (94 to 96\%) and these genomes share a close phylogenetic relatedness. However, amino acid sequence of CTLV-ML genome possesses low sequence identity (23 to $25 \%$ ) with CVA. Comparison of the CTLV-ML genome with other capilloviruses suggests that CTLV-ML is equally similar or dissimilar with ASGV, CTLV-K, CTLV-L, and ASGV-P with 13 to $16 \%$ divergence in ORF1, and maintained an equal genetic distance from capilloviruses infecting Rosaceae (ASGV and ASGV-P), Rutaceae (CTLV-K), and Liliaceae (CTLV-L) members. One of the mysteries of capilloviruses is how these viruses that infect a diverse group of plants-pome fruit, citrus, and lily - that share so much homology in their genomes. One of these plants may be the original host and, possibly, the others are secondary hosts that got infected by unknown means from an as-yet undetermined primary source. Although there is no good evidence for vector spread naturally, it seems unlikely that this virus would have been transmitted mechanically in an accidental fashion between such unrelated plants. Moreover, infections in citrus and lily are symptomless and these hosts are vegetatively propagated, and it is hard to see how infections could be spread within each crop once the initial infection occurred.

Even though the ORF1 of CTLV-ML exhibits 84 to $87 \%$ sequence identity with other capilloviruses (except CVA), there are two highly variable regions located between amino acids 532 and 570 (variable region I, 15 to $18 \%$ identity), and amino acids 1,583 and 1,868 (variable region II, 56 to $62 \%$ identity). Variable region II is located in the area in which the highly conserved MP ORF is located in a different reading frame. It is interesting to have one ORF with highly conserved amino acids and the other overlapping ORF in a different reading frame with a variable region. The high amino acid sequence identity of ORF1, MP, and CP of CTLV-K, CTLV-ML, CTLV-L, and ASGV-P with the corresponding ORFs of ASGV supports their designation as strains of

TABLE 5. Infection of Phaseolus vulgaris cv. Light Red Kidney bean plants with in vitro transcripts from Citrus tatter leaf virus from Meyer lemon (CTLV-ML) cDNA clones

\begin{tabular}{lc}
\hline cDNA clone $^{\mathrm{a}}$ & Infected/inoculated $^{\mathrm{b}}$ \\
\hline pCTLV-1 & $2 / 5$ \\
pCTLV-42 & $4 / 4$ \\
pCTLV-64 & $1 / 5$ \\
pCTLV-65 & $1 / 5$ \\
pCTLV-66 & $2 / 5$ \\
pCTLV-80 & $1 / 4$ \\
pCTLV-81 & $4 / 4$ \\
\hline
\end{tabular}

a In vitro transcripts inoculated to four to five bean plants and in vitro transcripts from 11 cDNA clones did not produce symptoms on kidney bean plants.

b Number of plants infected/number of plants inoculated.

TABLE 4. Effect of temperature on the infection of three bean cultivars by Citrus tatter leaf virus from Meyer lemon (CTLV-ML)

\begin{tabular}{|c|c|c|c|c|c|c|}
\hline \multirow[b]{2}{*}{ Incubation $\left({ }^{\circ} \mathrm{C}\right)^{\mathrm{b}}$} & \multicolumn{2}{|c|}{ LRK } & \multicolumn{2}{|c|}{ FCRK } & \multicolumn{2}{|c|}{ Pinto } \\
\hline & Local lesions & Systemic symptoms & Local lesions & Systemic symptoms & Local lesions & Systemic symptoms \\
\hline $19, \mathrm{GC}$ & $0.4 \pm 0.5$ & $5 / 5$ & $0.0 \pm 0.0$ & $4 / 4$ & $29.1 \pm 11.8$ & $0 / 4$ \\
\hline $22, \mathrm{GC}$ & $3.6 \pm 4.1$ & $9 / 9$ & $4.6 \pm 5.9$ & $4 / 4$ & $29.4 \pm 15.8$ & $0 / 6$ \\
\hline $24-29, \mathrm{GH}$ & $58.9 \pm 19.2$ & $0 / 7$ & $96.3 \pm 70.0$ & $0 / 4$ & $51.7 \pm 17.7$ & $0 / 4$ \\
\hline $26-34, \mathrm{GH}$ & $58.8 \pm 27.9$ & $0 / 6$ & $89.0 \pm 43.0$ & $0 / 4$ & $5.3 \pm 4.8$ & $0 / 6$ \\
\hline $32, \mathrm{GC}$ & $53.7 \pm 20.8$ & $0 / 6$ & $69.1 \pm 19.7$ & $0 / 4$ & $2.5 \pm 2.1$ & $0 / 5$ \\
\hline
\end{tabular}

${ }^{a}$ Primary leaves of bean cultivars inoculated with virus inoculum (1:10 dilution). Numbers represent average number of local lesions per leaf from 10 to 20 inoculated leaves. Experiment was repeated three times and representative data from one experiment is presented. Local lesions and systemic symptoms shown for light red kidney (LRK), Frijoles Colorados red kidney (FCRK), and pinto beans.

${ }^{\mathrm{b}}$ Incubation temperatures for growth chamber (GC), growth room (GR), and greenhouse (GH). 
ASGV, the type member of the genus Capillovirus (19,22,28; this study). However, these viruses differ substantially from each other in amino acid sequence of the variable regions I and II in ORF1, as would be expected for distinct species of a genus. Isolates of ASGV also differ substantially in variable region II,
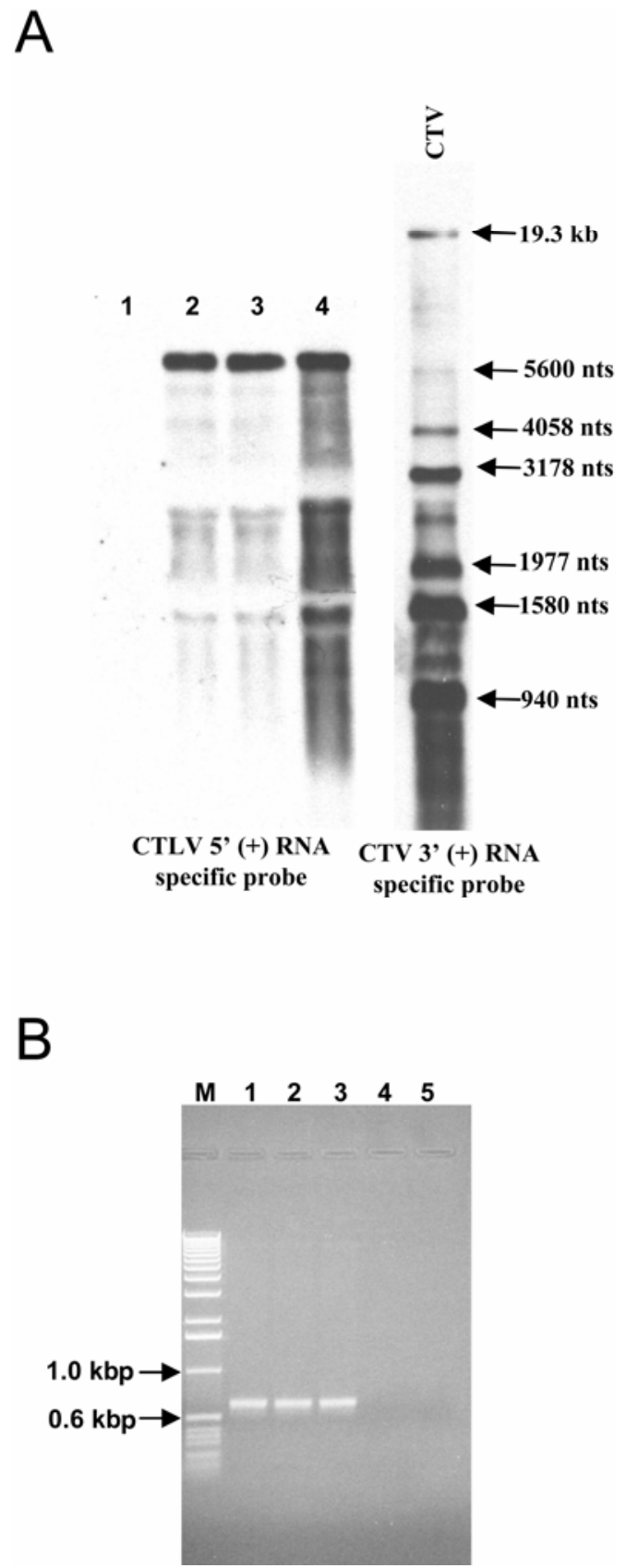

Fig. 5. Analysis of Phaseolus vulgaris cv. light red kidney bean plants infected with in vitro transcripts from full-length cDNA clones of Citrus tatter leaf virus from Meyer lemon (CTLV-ML). A, Northern blot hybridization of total RNA extracted from healthy (lane 1), a representative of two bean plants infected with in vitro transcripts from pCTLV-ML-66 (lane 2) and pCTLVML-81 (lane 3), and wild-type virus infected bean leaves (lane 4). A similar hybridization profile was observed with total RNA from other bean plants infected with in vitro transcripts (not shown). The blots hybridized with a $5^{\prime}$ positive-stranded RNA-specific probe. Citrus tristeza virus (CTV)-specific RNAs hybridized with a $3^{\prime}$ positive-stranded RNA-specific probe was used as molecular size marker. The sizes of CTV-specific RNAs are indicated at right side of the blot. B, Agarose gel electrophoresis (1.0\% in Tris-acetate EDTA buffer) of reverse-transcription polymerase chain reaction (RT-PCR) products of total RNA extracted from cloned viruses, CTLV-ML-66 (lane 1) and CTLVML-81(lane 2), and wild-type virus (lane 3) infected bean plants. Lane 4, healthy control; lane 5, water control for RT-PCR; M, DNA molecular size marker. with 53.2 to $99.3 \%$ sequence identity among 15 isolates and sequence variants (13). Although variable regions I and II of CTLV-ML differ substantially from other capilloviruses, CTLVML should be considered as a strain of ASGV based on molecular criteria defined for species in the Capillovirus genus, because the ORF1 and CP are conserved with 84 to $96 \%$ identity (1). It is puzzling how these viruses acquire the variable regions into their replication-associated polyproteins. It is possible that the variable regions present in the genomes of capilloviruses might play an important role in virus biology. Perhaps presence of variable regions in capillovirus genomes should be considered as a taxonomic characteristic for defining virus species in the genus Capillovirus.

Sequence analysis of two independent full-length cDNA clones suggests that they are sequence variants with $99.7 \%$ identity. CTLV-ML maintained in citrus plants after single-lesion isolation on red kidney bean plants suggests that the differences found between two clones might be attributed to errors by viral RNA polymerase during viral RNA replication (4). Similar sequence variants were also observed with ASGV (13).

CTLV-ML infects citrus trees systemically, but many cultivars are symptomless and symptom expression in citrus requires a long incubation period of up to 3 to 6 months. Therefore, developing an assay system with herbaceous indicator host was needed to further examine the biology of the virus and assay inoculations with infectious in vitro transcripts obtained from cDNA clones. In previous work, CTLV-ML induced local lesions on primary leaves of kidney bean plants, followed by occasional systemic symptoms (7). We found that LRK and FCRK bean plants incubated at 19 or $22^{\circ} \mathrm{C}$ provided a good herbaceous systemic assay host. The inconsistent systemic infection of LRK bean plants noticed at higher ambient temperatures was not observed when LRK and FCRK bean plants were kept at 19 or $22^{\circ} \mathrm{C}$. In contrast, Tobacco mosaic virus (TMV) induces a hypersensitive reaction (HR) in Nicotiana tabacum cv. Samsun $\mathrm{N}^{\prime} \mathrm{N}^{\prime}$ plants at temperature $<28^{\circ} \mathrm{C}$ whereas, at temperatures $>28^{\circ} \mathrm{C}$, no HR occurs and TMV moves systemically (12). It appears that increased susceptibility of bean plants to systemic infection of CTLV at low temperatures might be due to a different phenomenon than what was observed with TMV in N. tabacum cv. Samsun plants. Szittya et al. (23) reported that low temperatures inhibit RNA silencing-mediated defense, controlled by 21 - to 26-nt small interfering RNAs and, thus, host plants become more permissible for infection by plant viruses. It is possible that the increased susceptibility of LRK and FCRK bean plants to systemic infection at lower temperatures is due to a decreased effectiveness of a silencing-mediated defense at these temperatures.

Although an infectious cDNA clone of lily isolate of CTLV (later it was named as ASGV) was developed (19), the gene functions and gene expression strategy of capilloviruses are poorly studied. Infectious in vitro transcripts of CTLV-ML and a herbaceous systemic assay host can be used in a reverse genetic approach to facilitate understanding of the genetic basis of the biology of this virus and the roles of the regions of variable amino acids in the viral polymerase in virus biology by introducing mutations or creating chimeras. Construction of infectious cDNA clones of CTLV-ML is an important step forward in understanding the molecular basis of the virus-induced bud union incompatibility of citrus trees grafted on trifoliate rootstock, which is a critical component in developing management strategies for this problem.

Recently, we characterized sgRNAs produced by CTLV-ML and found a sgRNA with CP coding sequences even though capilloviruses do not encode a separate ORF for CP (24); instead, the $\mathrm{CP}$ is contiguous with replication-associated proteins. However, there is no experimental evidence whether capilloviruses express CP through a sgRNA or a polyprotein or a combination of both. Availability of infectious cDNA clones of CTLV-ML would 
facilitate examining the Capillovirus gene functions and mechanism of gene expression strategy by introducing mutations into infectious cDNA clone.

\section{ACKNOWLEDGMENTS}

We thank C. Robertson for maintaining CTLV-ML-infected citrus plants in the greenhouse, and T. Shilts and J. Cook for their technical help. This research was supported in part with grants from the Florida Citrus Production Research Advisory Council (FCPRAC).

\section{LITERATURE CITED}

1. Adams, M. J., Antoniw, J. F., Bar-Joseph, M., Brunt, A. A., Candresse, T., Foster, G. D., Martelli, G. P., Milne, R. G., and Fauquet, C. M. 2004. The new plant virus family Flexiviridae and assessment of molecular criteria for species demarcation. Arch. Virol. 149:1045-1060.

2. Bronson, C., Gaskalla, R., and Kessinger, M. 2004. Annual Report, Florida Citrus Budwood Protection Program. Bureau of Citrus Budwood Registration, Winter Haven, FL.

3. Calavan, E. C., Christiansen, D. W., and Roistacher, C. N. 1963. Symptoms associated with tatter-leaf virus infection of Troyer citrange rootstocks. Plant Dis. Rep. 47:971-975.

4. Drake, J. W., and Holland, J. J. 1999. Mutation rates among RNA viruses. Proc. Natl. Acad. Sci. USA 96:13910-13913.

5. Garnsey, S. M. 1964. Detection of tatter leaf virus of citrus in Florida. Proc. Fla. State Hortic. Soc. 77:106-109.

6. Garnsey, S. M. 1970. Viruses in Florida's Meyer lemon trees and their effects on other citrus. Proc. Fla. State Hortic. Soc. 83:66-71.

7. Garnsey, S. M. 1974. Mechanical transmission of a virus that produces tatter leaf symptoms in Citrus excelsa. Pages 137-140 in: Proc. Conf. Int. Organ. Citrus Virol. 6th. IOCV, Riverside, CA.

8. Garnsey, S. M., and Jones, J. W. 1968. Relationship of symptoms to the presence of tatter-leaf virus in several citrus hosts. Pages 206-212 in: Proc. Conf. Int. Organ. Citrus Virol. 4th. IOCV, Riverside, CA.

9. Hilf, M. E. 2008. An immunocapture RT-PCR procedure using Apple stem grooving virus antibodies facilitates analysis of Citrus tatter leaf virus from the original Meyer lemon host. Plant Dis.92:746-750.

10. Jelkmann, W. 1995. Cherry virus A: cDNA cloning of dsRNA, nucleotide sequence analysis and serology reveal a new plant capillovirus in sweet cherry. J. Gen. Virol. 76:2015-2024.

11. Kumar, S., Tamura, K., and Nei, M. 2004. MEGA3: Integrated software for molecular evolutionary genetics analysis and sequence alignment. Brief. Bioinf. 5:150-163.

12. Lacomme, C., and Cruz, S. S. 1999. Bax-induced cell death in tobacco is similar to the hypersensitive response. Proc. Natl. Acad. Sci. USA 96:7956-7961.

13. Magome, H., Yoshikawa, N., Takahashi, T., and Miyakawa, T. 1997. Molecular variability of the genomes of capilloviruses from apple,
Japanese Pear, European pear and citrus trees. Phytopathology 87:389396.

14. Martelli, G. P., Adams, M. J., Kreuze, J. F., and Dolja V. V. 2007. Family Flexiviridae: A case study in virion and genome plasticity. Annu. Rev. Phytopathol. 45:73-100.

15. Melcher, U. 2000. The ' $30 \mathrm{~K}$ ' superfamily of viral movement proteins. J. Gen. Virol. 81:257-266.

16. Miyakawa, T., and Ito, T. 2000. Tatter leaf-citrange stunt. In: Compendium of Citrus Diseases. American Phytopathological Society Press, St. Paul, MN.

17. Miyakawa, T., and Matsui, C. 1977. A budunion abnormality of Satsuma mandarin on Poncirus trifoliata rootstock in Japan. Pages 125-131 in: Proc. Conf. Int. Organ. Citrus Virol. 7th. IOCV, Riverside, CA.

18. Nishio, T., Kawai, A., Takahashi, T., Namba, S., and Yamashita, S. 1989. Purification and properties of Citrus tatter leaf virus. Ann. Phytopathol. Soc. Jpn. 58:416-425.

19. Ohira, K., Namba, S., Rozanov, M., Kusumi. T., and Tsuchizaki, T. 1995. Complete sequence of an infectious full-length cDNA clone of citrus tatter leaf capillovirus: comparative sequence analysis of capillovirus genomes. J. Gen. Virol. 76:2305-2309.

20. Sambrook, J., and Russell, D. W. 2001. Molecular Cloning: A Laboratory Manual, third ed. Cold Spring Harbor Laboratory Press, Cold Spring Harbor, NY.

21. Semancik, J. S., and Weathers, L. G. 1965. Partial purification of a mechanically transmissible virus associated with tatter leaf of citrus. Phytopathology 55:1354-1358.

22. Shim, H., Min, Y., Hong, S., Kwon, M., Kini, D., Kim, H., Choi, Y., Lee, S., and Yang, J. 2004. Nucleotide sequence of a Korean isolate of apple stem grooving virus associated with black necrotic leaf spot disease on pear (Pyrus pyrifolia). Mol. Cells 18:192-199.

23. Szittya, G., Silhavy, D., Molnar, A., Havelda, Z., Lovas, A., Lakatos, L., Banfalvi, Z., and Burgyan, J. 2003. Low temperature inhibits RNA silencing-mediated defense by the control of siRNA generation. EMBO J. 22:633-640.

24. Tatineni, S., Afunian, M. R., Gowda, S., Hilf, M. E., Bar-Joseph, M., and Dawson, W. O. Characterization of the 5'- and $3^{\prime}$-terminal subgenomic RNAs produced by a capillovirus: evidence for a CP subgenomic RNA. Virology (In press.)

25. Thompson, J. D., Higgins, D. G., and Gibson, T. J. 1997. CLUSTAL W: Improving the sensitivity of progressive multiple sequence alignment through sequence weighting, position-specific gap penalties and weight matrix choice. Nucleic Acid Res. 22:4673-4680.

26. Wallace, J. M., and Drake, R. J. 1962. Tatter leaf, a previously undescribed virus effect on citrus. Plant Dis. Rep. 46:211-212.

27. Wallace, J. M., and Drake, R. J. 1963. New information on symptom effects and host range of the citrus tatter leaf virus. Plant Dis. Rep. 47:352-353.

28. Yoshikawa, N., Sasaki, E., Kato, M., and Takahashi, T. 1992. The nucleotide sequence of apple stem grooving capillovirus genome. Virology 191:98-105. 